\title{
economics-of-security.eu
}

Konstantinos Drakos

\section{The Determinants of Terrorist Shocks' Cross-Market Transmission}

September 2009

Economics of Security Working Paper 17

European Security Economics

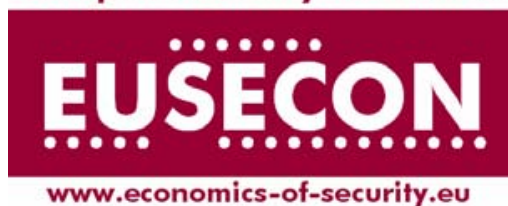


Economics of Security Working Paper Series

Correct citation: Drakos, K. (2009). "The Determinants of Terrorist Shocks' Cross-Market Transmission". Economics of Security Working Paper 17, Berlin: Economics of Security.

First published in 2009

(c) Konstantinos Drakos 2009

ISSN: $1868-0488$

For further information, please contact:

Economics of Security, c/o Department of International Economics, German Institute for Economic Research (DIW Berlin), Mohrenstr. 58, 10117 Berlin, Germany.

Tel: $+49(0) 3089789-277$

Email: eusecon@diw.de

Website: www.economics-of-security.eu 


\title{
The determinants of terrorist shocks' cross-market transmission
}

\author{
Konstantinos Drakos**
}

\begin{abstract}
The determinants of the cross-market transmission mechanism for terrorist shocks are explored, focusing on two major terrorist events and 68 national stock markets. We generate daily abnormal returns from a three-factor world asset pricing model. Abnormal returns are then regressed on proxies of three transmission mechanisms; a world integration channel, a bilateral integration channel, and a liquidity channel. Our findings indicate that terrorism shocks are diffused cross-nationally, and moreover this diffusion is non-uniform. We find empirical support for all three channels when considered separately. The bilateral integration channel contains the highest explanatory power since we find that a third country's trade linkages with the "ground-zero" country explain about $24 \%$ of the stock market reaction. A country's share in the world trade, a proxy for the world integration channel, is able to explain about $12 \%$ of abnormal return variation, while the liquidity channel exhibits the lowest predictive power, with the value of stock trading explaining about $6 \%$. A hybrid model, were proxies for all channels are included, shows that only the bilateral trade linkages with the "ground-zero" country are significant determinants of the stock market reaction.
\end{abstract}

Keywords: Linkages, Stock Market Return, Terrorism.

JEL: F36, F32, G15, C21, C23.

\footnotetext{
* Assistant Professor, Department of Accounting and Finance, Athens University of Economics and Business, and Network for the Economic Analysis of Terrorism (DIW Berlin-European Commission, Directorate General: Justice, Freedom and Security), Email: kdrakos@aueb.gr.

* The author acknowledges financial support by the $7^{\text {th }}$ Framework Program (Grant Agreement 218105).
} 


\section{Introduction}

In the post 9/11 era a new literature emerged, whose main aim has been to investigate various aspects of terrorism shocks' impacts on capital markets. The extant literature has established the significant - and immediate - negative reaction, to major terrorist attacks, of "ground-zero" countries' capital markets (Abadie and Gardeazabal 2003; Carter and Simkins 2004; Chen and Siems 2004; Drakos 2004; Eldor and Melnick 2004; Maillet and Michel 2005; Gulley and Sultan 2006; Amélie and Darné 2006; Nikkinen et al., 2008). This literature has also shown that significant negative reactions are also observed to third countries' markets.

However, an apparent gap in the literature, and in general of our understanding of the issue, relates to what is the underlying diffusion mechanism of major terrorist shocks. In other words, although we suspect that such shocks are indeed transmitted crossnationally, we have no concrete evidence regarding the determinants of their crosssectional variation. To put simply, we do not know why and how much third countries react in the occurrence of a major terrorist incident in another country. Clearly, providing an answer to this question would be of value for policy makers and supervision authorities, but more importantly for portfolio managers. Essentially, knowledge of these reaction patterns could assist portfolio managers in assessing whether diversification is possible. For instance, if terrorism shocks exhausted their effect within the "ground-zero" country, then they could be thought as being part of its idiosyncratic risk, and therefore able to be diversified away. If however terrorism shocks were diffused across markets, the diversification scope would depend on the pattern of diffusion. For instance the diversification gains would evaporate if shocks spread uniformly. In contrast, if shocks 
are non-uniformly diffused, diversification would be possible, provided that one could pin down the basic anatomy of the transmission mechanism.

Casual empiricism suggests that major shocks, especially of an adverse nature, or crises, even if considered as being mainly local, tend to diffuse cross-nationally. This diffusion is known as contagion, broadly defined as the spread of market disturbances from one country to another. A burgeoning literature has provided the theoretical underpinnings for several alternative explanations for the spread of shocks from their original location (the "ground-zero" country) to third countries (for excellent and extensive reviews see Wolf 1999; Dornbusch et al., 2000). One explanation places emphasis on economic linkages, where essentially the spillover to a given third country depends on the degree of its integration with the world markets (Calvo and Reinhart 1996; Masson 1998; Forbes and Rigobon 2002). We hereafter call this diffusion mechanism the world integration channel. Another explanation that has been proposed, similar in spirit, suggests that the transmission of shock to a country is facilitated by its economic ties with the "ground-zero" country. We hereafter call this transmission mechanism bilateral integration channel. Another class of explanations highlights the role of various 'irrational' phenomena triggered by investors' behavior (Calvo and Mendoza 2001; Pritsker 2001; Kodres and Pritsker 2002). Among this class, we consider the role of liquidity constraints arising in the event of a major shock that may lead investors to sell assets in third countries to meet margin calls. Hence, according to this channel the contagion increases with a country's capital market liquidity. We hereafter call this contagion mechanism the liquidity channel. 
In the present study we make a first attempt to explore the determinants of terrorist shock diffusion. In particular, focusing in the post $9 / 11$ period, we model stock market reaction patterns across 68 countries on the days of two major terrorist events (Madrid attack, London attack). Reaction is measured by the daily abnormal return, controlling for a three-factor world asset pricing as well as distributed lags of domestic returns. Then the analysis investigates whether the three alternative transmission channels contain any significant explanatory power for abnormal returns.

Our empirical findings suggest that terrorism shocks are indeed diffused crossnationally, and moreover this diffusion is non-uniform. In particular, we find empirical support for the world integration channel since trade and financial linkages to world markets emerge as important 'predictors' for a country's stock market reaction to terrorist events. Among the trade and financial linkages considered, a country's share in the world trade is able to explain the highest percentage of abnormal return variation in the occurrence of a major terrorist incident (about $12 \%$ ). Additionally, the bilateral integration channel is also in operation, where we find that a third country's trade linkages with the "ground-zero" country explain about $24 \%$ of stock market reaction. Moreover we find empirical support for the liquidity channel with the value of stock trading explaining about $6 \%$ of stock market reaction. A hybrid model including proxies for all three channels is able to explain about $24 \%$ of abnormal return variation in the occurrence of major terrorist shocks.

The remainder of the paper is as follows. Section 2 provides the general setup within which one can model the transmission mechanism of terrorist shocks. Section 3 describes data sources, the construction of variables and their sample properties. Section 
4 presents the econometric methodology. Section 5 discusses the empirical findings. Finally, in Section 6 we conclude.

\section{Returns' generation and shock transmission}

\subsection{The baseline pricing framework}

Our departure point is the asset pricing framework driving international stock market returns. The first building block is the standard Capital Asset Pricing Model (Sharpe 1964; Lintner 1965), where in an international context the global value-weighted market portfolio is the relevant risk factor (Grauer et al. 1976; Adler and Dumas 1983). Then we consider an international version of the three-factor model (Fama and French 1993, 1996) as follows:

$E\left(r_{i, t}\right)=\lambda_{\text {wmp }} \beta_{i, w m p}+\lambda_{h m l} \beta_{i, h m l}+\lambda_{s m b} \beta_{i, s m b}$

Where $E\left(r_{i, t}\right)$ is the expected return on stock index $(i)$ at time $(t)$ in excess of a risk-free rate, $\lambda_{w m p}=E\left(r_{w m p, t}\right), \lambda_{h m l}=E\left(r_{h m l, t}\right)$, and $\lambda_{s m b}=E\left(r_{s m b, t}\right)$ are the risk premia of the World Market Portfolio, the High-minus-Low earnings-price ratio portfolio, and the Small-minus-Big market value portfolio respectively. Similarly, $\beta_{i, w m p}, \beta_{i, h m l}$, and $\beta_{i, s m b}$ are the betas of stock index $(i)$, measuring its sensitivity to each of the risk factors.

This relationship becomes estimable when we allow for a stochastic shock that generates possibly non-spherical deviations from the long-run as follows:

$\left(r_{i, t}\right)=r_{w m p, t} \beta_{i, w m p}+r_{h m l, t} \beta_{i, h m l}+r_{s m b, t} \beta_{i, s m b}+u_{i, t}$ 


\subsection{Introducing the terrorism shock}

We define $\left(m g t_{g z c, t}\right)$ as an impulse dummy, which denotes the occurrence of a major terrorist incident on day $(t)$ and country $(g z c)$, i.e the "ground-zero" country, when attains the value of unity. In contrast, when $\left(m g t_{g z c, t}\right)$ attains the value of zero there is no major-terrorist event and therefore denotes 'normal' periods. Thus, in order to investigate whether third countries' markets react to the news of major terrorist attacks in another country, we allow the return generation process to differ between 'normal' periods (i.e in the absence of major terrorist events) and periods where such events occur. So returns are determined as follows:

$r_{i, t}=r_{w m p, t} \beta_{i, w m p}+r_{h m l, t} \beta_{i, h m l}+r_{s m b, t} \beta_{i, s m b}+\gamma_{i}\left(m g t_{g z c, t}\right)+u_{i, t}, \quad \forall i \neq g z c$

The parameter $\left(\gamma_{i}\right)$ captures the sensitivity of third countries' returns to the news of terrorist attack occurrence in another country and our prior is that it will carry a negative sign. Thus, provided that $\left(\gamma_{i}\right)<0$, the realization of a terrorist shock will be diffused to third countries. Moreover, the returns in 'normal' periods (i.e in the absence of major terrorist events) are driven by fundamentals as described by a standard asset pricing model. In contrast during non-normal periods, although fundamentals continue to play a role, returns exhibit a transitory deviation from equilibrium. Hence, the following holds:

$E\left(r_{i, t} \mid m g t_{g z c, t}=1\right)-E\left(r_{i, t} \mid m g t_{g z c, t}=0\right)=\gamma_{i}<0, \quad \forall i \neq g z c$

This expression suggests that third countries' abnormal returns on days that major terrorist events occur are, on average, lower than returns on normal periods. This is a testable implication that we will explore later on. 


\subsection{A look into potential diffusion mechanisms}

Recall that our main purpose is to investigate the determinants of third countries' stock market reactions to terrorism shocks. To tackle this issue we consider three types of potential transmission channels. The first focuses on a country's economic linkages with world markets and in particular considers trade and financial linkages. If a country has a high degree of real (trade) or financial linkages with global markets, it is expected to exhibit a more extensive response given a shock in another country. In contrast, countries that are not sufficiently integrated are to some extent immune to the shock (Calvo and Reinhart 1996; Masson 1998; Forbes and Rigobon 2002). The second brings to centre stage a country's relationship vis-à-vis the "ground-zero" country, and in particular considers their bilateral trade and financial linkages. The third emphasizes a country's stock market liquidity. The literature advocates that in the occurrence of a major terrorist event, causing downward pressure to a country's asset prices, market participants would benefit most from selling in highly liquid markets since this lowers the impact of their sell orders on prices. (Kodres and Pritsker 2001; Calvo and Mendoza 2001).

Going back to the return generation process, we investigate whether third countries' reaction to major terrorist events is explained by a given channel $\left(x_{i, t}\right)$. Then in the spirit of Bekaert and Harvey $(1995,1997), \mathrm{Ng}$ (2000), Forbes and Rigobon (2002) and Bekaert et al. (2005), we allow third countries' sensitivity to be time-varying as follows:

$\gamma_{i}=\delta_{0}+\delta_{i, 1}\left(x_{i, t}\right)$

Then expression (3) becomes: 


$$
\begin{aligned}
r_{i, t} & =r_{w m p, t} \beta_{i, w m p}+r_{h m l, t} \beta_{i, h m l}+r_{s m b, t} \beta_{i, s m b}+\left[\delta_{0}+\delta_{i, 1}\left(x_{i, t}\right)\right] *\left(m g t_{g z c, t}\right)+u_{i, t}= \\
& =r_{w m p, t} \beta_{i, w m p}+r_{h m l, t} \beta_{i, h m l}+r_{s m b, t} \beta_{i, s m b}+\delta_{0}\left(m g t_{g z c, t}\right)+\delta_{i, 1}\left(x_{i, t}\right) *\left(m g t_{g z c, t}\right)+u_{i, t}
\end{aligned}
$$

This expression nests various alternative possibilities regarding the diffusion of terrorist shocks, described below:

Case 1: major terrorism events do not affect third countries' capital markets; $\delta_{0}=\delta_{i, 1}=0$

Case 2: major terrorist events affect third countries in a uniform manner, irrespectively of their exposure to each transmission channel; $\delta_{0}<0 \wedge \delta_{i, 1}=0$

Case 3: the diffusion of shocks is non-uniform and mirrors differential exposures to the transmission channel; $\delta_{0}<0, \delta_{i, 1}<0$

Suppose for the time being that the sign configuration shown in Case 3 is valid then it would imply that:

$E\left(r_{i, t} \mid m g t_{g z c, t}=1\right)-E\left(r_{i, t} \mid m g t_{g z c, t}=0\right)=\delta_{0}+\delta_{i, 1} E\left(x_{i, t}\right)<0, \quad \forall i \neq g z c$

This expression has two testable implications: (a) third countries' abnormal returns (stock market reactions) are significantly lower on days of major terrorist events' occurrence, i.e terrorist shocks are diffused cross-nationally, and (b) the size of reaction (absolute magnitude of abnormal returns) increases with a country's exposure to a given channel. 


\section{Data issues}

\subsection{Returns and systematic risk factors}

Daily closing prices from $1 / 1 / 2002$ to $30 / 12 / 2005$ in local currencies for broad stock market indices where obtained from Datastream for the following countries (detailed list of stock indices by country is provided in the Appendix, part A): Argentina, Australia, Austria, Bahrain, Belgium, Brazil, Bulgaria, Canada, Chile, Colombia, Croatia, Cyprus, Czech Republic, Denmark, Egypt, Equador, Estonia, Finland, France, Germany, Greece, Hong Kong, Hungary, Iceland, India, Indonesia, Ireland, Israel, Italy, Japan, Jordan, Korea, Kuwait, Latvia, Lebanon, Lithuania, Luxemburg, Malaysia, Malta, Mexico, Netherlands, New Zealand, Norway, Oman, Pakistan, Peru, Philippines, Poland, Portugal, Qatar, Romania, Russian Federation, Saudi Arabia, Singapore, Slovakia, Slovenia, Spain, Sri Lanka, Sweden, Switzerland, Taiwan, Thailand, Turkey, United Arab Emirates, United Kingdom, United States, and Venezuela.

Consider a vector of stock market index prices, $\left(I_{i, t}\right)$, where $(i)$ and $(t)$ denote country and day respectively. The daily return $\left(r_{i, t}\right)$ is calculated as follows:

$\left(r_{i, t}\right)=\left[\frac{I_{i, t}-I_{i, t-1}}{I_{i, t-1}}\right] * 100$

The three benchmark portfolios denoting the risk factors are proxied by the global equity market portfolios maintained by World Morgan Stanley Capital International (MSCI World) indices as follows: $\left(r_{w m p, t}\right)$ defined as the return on the world market portfolio, $\left(r_{s m b, t}\right)$ defined as the difference between the return on a world portfolio of small capitalization stocks and the return on a portfolio of large capitalization stocks (smb, small minus big), $\left(r_{h m l, t}\right)$ defined as the difference between the return on a world 
portfolio of high book-to-market stocks (value) and the return on low book-to-market (growth) stocks (hml, high minus low), which proxies the value or distress premium.

\subsection{Construction of transmission channels' proxies}

Let $(i)$ denote the country and $(y)$ the year. To measure a country's trade integration with world markets we use data from the IMF's International Financial Statistics (IFS) database. The IFS provides the value (in US Dollars) of trade (imports and exports) between a given country and all of its trading partners. Then for each country we calculate the sum of its exports $\left(X_{i, y}\right)$ and imports $\left(M_{i, y}\right)$, and measure what percentage it represented in global international trade $\left[\sum_{\text {world }}(M+X)_{i, y}\right]$ :

trade $_{i, y}=\left[\frac{(M+X)_{i, y}}{\sum_{\text {world }}(M+X)_{i, y}}\right] * 100$

We also consider whether there are any differences between the explanatory powers of export and import linkages. In order to do so we construct the following variables:

$$
\begin{aligned}
& \operatorname{imp}_{i, y}=\left[\frac{(M)_{i, y}}{\sum_{\text {world }}(M)_{i, y}}\right] * 100 \\
& \exp _{i, y}=\left[\frac{(X)_{i, y}}{\sum_{\text {world }}(X)_{i, y}}\right] * 100
\end{aligned}
$$

A country's financial linkages with world markets are based on the IMF's Coordinated Portfolio Investment Survey (CPIS) database, which provides information on the stock of cross-border holdings of securities (equity and debt securities) valued at 
market prices prevailing at the end of each year, and broken down by the economy of residence of the issuer of the securities. Note that these securities are not part of the balance of payments data categories of direct investment, reserve assets, or financial derivatives. The CPIS provides information on the following: (i) inward $\left(\right.$ eqin $\left._{i, y}\right)$ and outward $\left(\right.$ eqout $\left._{i, y}\right)$ investment on equity securities, (ii) inward $\left(\right.$ dein $\left._{i, y}\right)$ and outward $\left(\right.$ deout $\left._{i, y}\right)$ investment in debt securities. In a manner similar to the trade linkages, we construct a proxy for the degree of a country's financial linkages with the world as follows:

fina $_{i, y}=\left[\frac{[(\text { eqin }+ \text { eqout })+(\text { dein }+ \text { deout })]_{i, y}}{\sum_{\text {world }}[(\text { eqin }+ \text { eqout })+(\text { dein }+ \text { deout })]_{i, y}}\right] * 100$

We also construct alternative proxies by breaking total portfolio investment assets into equity and debt securities as follows:

$$
\begin{aligned}
e q u_{i, y} & =\left[\frac{[(\text { eqin }+ \text { eqout })]_{i, y}}{\sum_{\text {world }}[(\text { eqin }+ \text { eqout })]_{i, y}}\right] * 100 \\
\text { debt }_{i, y} & =\left[\frac{[(\text { dein }+ \text { deout })]_{i, y}}{\sum_{\text {world }}[(\text { dein }+ \text { deout })]_{i, y}}\right] * 100
\end{aligned}
$$

In order to capture the linkages with the "ground-zero" country we resort to two metrics. The first captures bilateral trade linkages, and is defined as the percentage their bilateral imports and exports $\left(\text { bitrade }_{g z c}\right)_{i, v}$ represent to both countries' trade with the rest of the world; $\left\{\sum_{\text {world }}\left[\left(\operatorname{trade}_{i, y}\right)+\left(\right.\right.\right.$ trade $\left.\left.\left._{g z c, y}\right)\right]\right\}$ : 
$\operatorname{tradegzc}_{i, y}=\left[\frac{\left(\text { bitrade }_{g z c}\right)_{i, y}}{\sum_{\text {world }}\left[\left(\text { trade }_{i, y}\right)+\left(\text { trade }_{g z c, y}\right)\right]}\right] * 100$

The data for the trade bilateral linkages were obtained from the United Nation's Commodity Trade Statistics Database (COMTRADE). The UN also compiles a similar database covering services trade, however there are severe limitations due to a substantial portion of missing data.

The second measures a country's overall financial linkages with the "groundzero" country, defined as the percentage their bilateral financial linkages $\left(\text { bifina }_{g z c}\right)_{i, y}$ represent to both countries' financial linkages with the rest of the world; $\left\{\sum_{\text {world }}\left[\left(\right.\right.\right.$ fina $\left._{i, y}\right)+\left(\right.$ fina $\left.\left.\left._{g z c, y}\right)\right]\right\}:$

finagzc $_{i, y}=\left[\frac{\left(\text { bifina }_{g z c}\right)_{i, y}}{\sum_{\text {world }_{i}}\left[\left(\text { fina }_{i, y}\right)+\left(\text { fina }_{g z c, y}\right)\right]}\right] * 100$

Using data from the World Bank's World Development Indicators we proxy a country's stock market liquidity by two alternative metrics; the stock market capitalization $\left(M C_{i, y}\right)$ as a ratio to gross domestic product, and the value of stock trading $\left(V T_{i, y}\right)$ as a ratio to gross domestic product.:

$$
\begin{aligned}
& s m c_{i, y}=\left(\frac{M C_{i, y}}{G D P_{i, y}}\right) * 100 \\
& v s t_{i, y}=\left(\frac{V T_{i, y}}{G D P_{i, y}}\right) * 100
\end{aligned}
$$


In Table 1 we report the basic descriptive statistics for the potential transmission channel proxies, while in Table 2 we report their pairwise sample correlations. Note the strong correlation between any pair of proxies belonging to the same channel, which is indicative of the commonality in information that precludes their joint inclusion as explanatory variables in any model. In contrast, the correlations of proxies between channels are substantially lower, allowing one to consider combinations of channels as regressors.

----------Table 1----------

----------Table 2----------

\subsection{Identifying major terrorist attacks: the stimulus}

Apparently there is no hard definition of what constitutes a major-terrorist incident and consequently some arbitrariness in the choice of events is in order. We use the following terrorist incidents: the Madrid attack on March $11^{\text {th }} 2004$ and the London attack on July $7^{\text {th }} 2005$. Table 3 provides some important background information related to these attacks.

Table 3

\section{Econometric methodology}

We use a flexible empirical specification whose core is a three-factor world model where, apart from the current values of the risk factors, we also include up to five lags to capture any non-synchronization in trading. In addition, we allow for a similar autoregressive structure for country returns. In order to capture any calendar anomalies we use fixed month and day effects, over and above year effects (Gibbons and Hess 1981; Jaffe and 
Westerfield 1985; Kato and Shallheim 1985; Board and Sutcliffe 1988; Choudhry 2001). The employed baseline empirical model is of the following form:

$$
\begin{aligned}
\left(r_{i, t}\right) & =\alpha_{0}+\left(\sum_{j=0}^{5} \beta_{w m p, j} r_{w m p, t-j}\right)+\left(\sum_{j=0}^{5} \beta_{s m b, j} r_{s m b, t-j}\right)+\left(\sum_{j=0}^{5} \beta_{h m l, j} r_{h m l, t-j}\right)+\left(\sum_{j=1}^{5} \phi_{j} r_{i, t-j}\right) \\
& +(\text { year effects })+(\text { month effects })+(\text { day effects })+\mu_{i}+\varepsilon_{i, t}
\end{aligned}
$$

Given the panel dimension we condition on country heterogeneity allowing for an unobserved effect $\mu_{i}$ treated as random, assuming that $E\left(r_{i, t-j} \mu_{i}\right)=0 \quad \forall i, j, t$.

A well established empirical regularity is the volatility clustering exhibited by daily returns (Engle 1982; Bollerslev 1986). Thus, in order to control for this we employ a Pooled Panel GARCH (PP-GARCH hereafter) model for the conditional volatility of stock returns (Cermeno and Grier 2006). Although multivariate GARCH models are also available, they are not practical for most panel applications because they require the estimation of a large number of parameters which consumes degrees of freedom rapidly. In contrast, PP-GARCH estimation by imposing common dynamics on the variancecovariance process across cross-sectional units reduces the number of parameters dramatically ensuring parsimony. We then allow a more flexible specification for the error term with:

$E\left(\varepsilon_{i, t}\right)=0$ and $E\left(\varepsilon_{i, t}^{2}\right)=\sigma_{i, t}^{2}$

In particular, assuming that $\varepsilon_{i, t} \sim N\left[0, \Omega_{i, t}\right]$, i.e. are multivariate normal error terms with a time-varying conditional variance-covariance matrix produces a PP-GARCH 
model (Cermeno and Grier 2006). The variance-covariance matrix $\Omega_{i, t}$ is time-dependent and its diagonal and off-diagonal elements are given by the following equations:

$$
\begin{aligned}
& \sigma_{i, t}^{2}=\theta_{0}+\sum_{n=1}^{N} \theta_{n}^{*} \sigma_{i, t-n}^{2}+\sum_{l=1}^{L} \eta_{l} v_{i, t-l}^{2} \\
& \sigma_{i, j, t}=\psi_{0}+\sum_{n=1}^{p} \psi_{n} \sigma_{i, j, t-n}+\sum_{m=1}^{k} \rho_{m} v_{i, t-m} v_{j, t-m}, \text { for } i \neq j
\end{aligned}
$$

where the $\theta^{*}$ 's, $\psi$ 's, $\eta$ 's and $\rho$ 's denote unknown constant parameters to be estimated.

\subsection{The effect of transmission channels}

In order to investigate whether linkages contain significant information for

abnormal returns, we recover the residuals $\left(\hat{\varepsilon}_{i, t} \mid m g t_{g z c, t}=1\right)$ from model (19) focusing on the days of the two major terrorist events. It should be noted that due to the different time zones of countries included in the sample, one should correct for the non-synchronous trading. We have followed the standard practice of using the lag or the lead of the return for countries at different time zones accordingly. However, in order to avoid further complication of notation we denote all abnormal returns at time $(t)$.

Let $\left(x_{m, i, t}\right)$ denote the possible reaction determinant where $(m)$ denotes a particular transmission channel proxy. Then we project the residuals on each of these proxies allowing for up to a third-order polynomial to capture potential non-linearities:

$\left(\hat{\varepsilon}_{i, t} \mid m g t_{g z c, t}=1\right)=\gamma_{0}+\sum_{s=1}^{3} \gamma_{m, s}\left(x_{m, i, t}\right)^{s}+u_{m, i, t}$

After the estimation stage we proceed with three steps. Firstly, for each potential channel proxy, by the means of formal hypotheses testing, we establish the preferred 
specification (i.e linear, quadratic or cubic). Secondly, we explore whether each type of linkages contains significant explanatory power over abnormal returns by testing:

$H_{0}: \gamma_{m, s}=0, \forall m, s$

Provided that a particular set of hypotheses is rejected, it would imply that the associated channel of diffusion is in operation and furthermore, that the diffusion of terrorist shocks is non-uniformly distributed across countries. Thirdly we embark on a comparison between potential diffusion channels in terms of their relative explanatory power over abnormal returns.

\section{Empirical results}

\subsection{Preliminary unconditional analysis}

As a prelude to the subsequent econometric analysis we provide some descriptive statistics that will shed light in data properties. The sample mean of (pooled) realized returns excluding the days of major attacks was $0.092 \%$ with a standard deviation of 1.26 $\%$, while the corresponding figures on the days of these attacks were $-0.409 \%$ and 1.35

$\%$. This information is indicative of large negative market reactions on days of major attack occurrences.

\subsection{Main Results}

Before we move to the investigation of our main hypotheses, we first estimate the parameters of the three-factor world model under a set of alternative techniques and specifications, with the aim to select the one which more adequately fits daily returns. In particular, we use a Random-Effects, and three Pooled Panel GARCH models; a PPARCH(1), a PP-ARCH(2) and a PP-GARCH(1,1) (estimation results are given in Table A1 in the Appendix, part B). The RE model is outperformed by its PP-GARCH 
counterparts, since in every specification the parameters in the conditional volatility equation are highly significant, suggesting that volatility clustering is present. Then after a sequence of Likelihood Ratio tests, the PP-GARCH(1,1) emerges as the preferred specification.

Then, we recover the residuals obtained from the PP-GARCH(1,1) model, which we regress on each of the potential transmission channels, considering three competing specifications (a linear, a quadratic and a cubic). Based on formal hypotheses tests we selected the specification that best fitted the data (detailed results are provided in the in Tables A2-A6 in the Appendix, part B).

\subsubsection{The role of the world integration channel}

In Table 4 we report the results from projecting abnormal returns to proxies of the world integration channel corresponding to the selected specifications. All trade linkages' proxies contain significant explanatory power for abnormal returns. The relationship between abnormal returns and linkages is non-linear, and in particular is found to be cubic for overall trade and imports, while quadratic for exports. Turning now our attention to linkages' explanatory power (adjusted coefficient of determination) we find that overall trade linkages explain about $14.4 \%$, while imports and exports are able to explain about $14.5 \%$ and $11 \%$ of abnormal return variation.

\section{Table 4}

In Table 5 we report the results for the financial linkages with world markets. Total portfolio investment linkages account for $7 \%$ of abnormal returns' variation. However, the decomposition of total financial linkages into its main constituents, equity 
and debt linkages reveals that equity investment has a very poor explanatory power (about $2 \%$ ). In contrast, debt linkages explain about $8 \%$ of abnormal return variation.

Table 5

Thus, among the proxies for the world integration channel considered, overall trade linkages have the highest explanatory power over cross-country stock market reactions.

\subsubsection{The roles of the bilateral linkages and liquidity channels}

In Table 6 we summarize the estimation results from regressing abnormal returns on proxies of the bilateral integration and liquidity channels. Trade linkages with the "ground-zero" country emerge as the most important determinant of stock market reaction, accounting for about $24 \%$ of abnormal return variation. Financial linkages with the "ground-zero" countries are also significant, accounting for about $7 \%$ of abnormal return variation. The estimated parameters indicate that, in the occurrence of a major terrorist event in a given country, third countries' stock market reaction increases with their ties with the "ground-zero" country.

As it regards to the liquidity channel, we find that abnormal returns are significantly correlated both with the stock market capitalization and the value of stock market trading. In particular, stock market capitalization explains about $5.5 \%$ of stock market reactions while the value of trading about $6 \%$. These findings suggest that indeed more liquid markets tend to react more strongly as suggested by theory. 


\subsubsection{A hybrid model for stock market reactions}

Our estimation results suggest that all three transmission channels are in operation when considered separately. Now we construct a hybrid model that brings together all three with the aim to better fit observed stock market reactions. From each channel we select the proxy with the highest explanatory power provided that it is not collinear with the rest of the channel proxies, i.e. overall trade linkages with the world (world integration channel), trade linkages with the "ground-zero" country (bilateral integration channel) and stock market capitalization (liquidity channel). Table 7 summarizes the estimation results. The hybrid model accounts for $24 \%$ of abnormal return variation, whose explanatory power is comparable to that obtained from trade linkages with the "groundzero" country. The hypotheses tests for the significance of each channel, controlling for the presence of the other channels, indicate that only the bilateral integration channel is significant at all conventional levels.

\section{-Table 7}

\section{Conclusions}

In the present study we make a first attempt to investigate the underlying crossmarket transmission mechanism of major terrorist shocks, which has so far been unexplored. In particular, focusing in the post $9 / 11$ period, we use two major terrorist events (Madrid and London attacks) and model stock market reaction patterns across 68 countries. Reaction is measured by the daily abnormal return, controlling for a threefactor world asset pricing, as well as distributed lags of domestic returns. Then the analysis investigates three potential channels for the cross-country diffusion of terrorist shocks: (i) integration with world markets, (ii) linkages vis-à-vis the "ground-zero" country, and (iii) stock market liquidity. 
Our empirical findings suggest that terrorism shocks are indeed diffused crossnationally, and moreover this diffusion is non-uniform. In particular, we find empirical support for the world integration channel since trade and financial linkages emerge as significant predictors for a country's stock market reaction to terrorist events. Among the trade and financial linkages considered, a country's share in world trade is able to explain the highest percentage of abnormal return variation in the occurrence of a major terrorist incident. The bilateral linkages channel is also active where third countries' trade linkages with the "ground-zero" country account for about $24 \%$ of the cross-country variation in reaction to terrorist shocks. Moreover we find empirical support for the liquidity channel since stock market capitalization is also a significant determinant of stock market reaction. A hybrid model were all three channels are jointly included suggest that only bilateral trade linkages with the "ground-zero" country are significant determinants of stock market reaction.

These findings have important implications for supervision authorities but more importantly for portfolio managers. The non-uniform reaction to major terrorist shocks implies that there is ample scope for diversification. Future research could extend the set of explanatory variables including other structural country characteristics over and above linkages, such as market structure, ownership structure and liquidity. In addition, nonfinancial factors could also be explored, such as the impact of terrorism shocks on investor sentiment and risk aversion. 


\section{References}

Abadie, A and J. Gardeazabal, 2003. The economic costs of conflict: A case study of the Basque country. American Economic Review, 93(1), 113-32.

Adler, M. and B. Dumas, 1983. International portfolio selection and corporation finance: A synthesis. Journal of Finance, 38, 925-984.

Amélie, C. and O. Darné, 2006. Large shocks and the September $11^{\text {th }}$ terrorist attacks on international stock markets. Economic Modelling, 23, 683-698.

Bekaert, G. and C. Harvey, 1995. Time-varying world integration, Journal of Finance, 50, 403-444.

Bekaert, G. and C. Harvey, 1997. Emerging Equity Market Volatility. Journal of Financial Economics, 43, 29-77.

Bekaert, G., C. Harvey, and A. Ng, 2005. Market integration and contagion. Journal of Business, 78(1), 39-69.

Bollerslev, T., 1986. Generalised autoregressive conditional heteroscedasticity. Journal of Econometrics, 31, 307-327.

Board, J. and C. Sutcliffe, 1988. The Weekend effect in UK stock returns. Journal of Business Finance and Accounting, 15,199-213.

Calvo, S. and C. Reinhart, 1996. Capital flows to Latin America: is there evidence of contagion effect?. In G. Calvo, M. Goldstein, and E. Hochreiter, (eds)., Private Capital Flows to Emerging Markets after the Mexican Crisis. Washington, D.C.: Institute for International Economics.

Calvo. G. and E. Mendoza, 2000. Rational contagion and the globalization of securities markets. Journal of International Economics, 51(1), 79-113.

Carter, D. and B. Simkins, 2004. The market's reaction to unexpected, catastrophic events: the case of airline stock returns and the September $11^{\text {th }}$ attacks. Quarterly Review of Economics and Finance, 44, 539-558.

Cermeno, R. and K. Grier, 2006. Conditional heteroscedasticity and cross-sectional dependence in panel data: an empirical study of inflation uncertainty in the G7 countries. ch. 10, in Baltagi, B.H. (Ed.): Panel Data Econometrics, NorthHolland.

Chen, A. and T. Siems, 2004. The effects of terrorism on global capital markets. European Journal of Political Economy, 20, 349-366.

Choudhry, T., 2001. Month of the year effect and January effect in PreWW1 stock returns: evidence from a nonlinear GARCH model. International Journal of Finance and Economics, 6, 1-11.

Dornbusch, R., Park, Y. and S. Claessens, 2000. Contagion: understanding how it spreads. World Bank Research Observer, 15(2), 177-197.

Drakos, K., 2004. Terrorism-induced structural shifts in financial risk: airline stocks in the aftermath of the September $11^{\text {th }}$ terror attacks. European Journal of Political Economy, 20, 435-446.

Eldor, P. and R. Melnick, 2004. Financial markets and terrorism, European Journal of Political Economy, 20, 367-386.

Engle, R., 1982. Autoregressive conditional heteroscedasticity with estimates of the variance of United Kingdom inflation. Econometrica, 50, 987-1007.

Fama, E., and K. French, 1993. Common risk factors in the returns on stocks and bonds. Journal of Financial Economics 33, 3-56. 
Fama, E., and K. French, 1996. Multifactor explanations of asset pricing anomalies. Journal of Finance 51, 131-155.

Forbes, K. and R. Rigobon. 2002. No contagion, only interdependence: measuring stock market comovements. Journal of Finance, 57(5), 2223-2261.

Gibbons, M. and J. Hess, 1981. Day of the week effect and asset returns. Journal of Business, 54, 579-96.

Grauer, F., Litzenberger, R., and R. Stehle, 1976. Sharing rules and equilibrium in an international portfolio of stocks and bonds. Journal of Financial Economics, 3, 233-256.

Gulley, D. and J. Sultan, 2008. Risk premium, volatility, and terrorism: new evidence. Working paper Bentley College.

Jaffe, J. and R. Westerfield, 1985. The weekend effect in common stock returns: the international evidence. Journal of Finance, 40, 433-454.

Kato, K., and J. Shallheim, 1985. Seasonal and size anomalies in the Japanese stock market. Journal of Financial and Quantitative Analysis, 20(2), 243-260.

Kodres, L. and M. Pritsker 2002. A rational expectations model of financial contagion. Journal of Finance, 57(2), 769-799.

Lintner, J., 1965. The valuation of risky assets and the selection of risky investments in stock portfolios and capital budgets. Review of Economics and Statistics 47, 13-37.

Maillet, B. and L. Michel, 2005. The impact of the 9/11 events on the American and French stock markets. Review of International Economics, 13, 597-611.

Masson, P., 1998. Contagion: Monsoonal Effects, Spillovers, and Jumps between Multiple Equilibria. IMF Working Paper WP/98/142. International Monetary Fund, Washington, D.C.

National Counterterrorism Center, U.S. Department of State, 2005. Patterns of Global Terrorism: Part 4 Chronology of Significant Terrorist Events 1985-2005.

$\mathrm{Ng}$, A., 2000. Volatility Spillover Effects from Japan and the U.S. to the Pacific-Basin. Journal of International Money and Finance, 19, 207-233.

Nikkinen, J., Mohammad, O., Sahlstrom, P, and J. Aijo, 2008. Stock returns and volatility following the September 11 Attacks: evidence from 53 Equity Markets. International Review of Financial Analysis, 17, 27-46.

Pritsker, M., 2001. The channels for financial contagion, in Stijn Claessens, Kristin J. Forbes, eds., International Financial Contagion. Boston/Dordrecht/London: Kluwer Academic Publishers.

Sharpe, W., 1964. Capital asset prices: a theory of market equilibrium under conditions of risk. Journal of Finance 19, 425-442.

Wolf, H., 1999. International Asset Price and Capital Flow Comovements during Crisis: The Role of Contagion, Demonstration Effects, and Fundamentals. Paper presented at the World Bank/IMF/WTO conference on "Capital Flows, Financial Crises, and Policies," April 15-16, Washington, D.C. 


\section{Appendix}

A. List of stock market indices / country:

Merval / Argentina, ASX All Ordinaries Index / Australia, ATX / Austria, Bahrain Stock Exchange Index / Bahrain, BEL 20 / Belgium, Bovespa / Brazil, BSE SOFIX / Bulgaria, S\&P/TSX Composite Index / Canada, Chile General (IGPA) / Chile, IGBC Index / Colombia, CROBEX / Croatia, Cyprus General / Cyprus, Prague SE PX / Czech Republic, OMX Copenhagen / Denmark, ECU Price Index / Ecuador, Hermes Financial / Egypt, OMX Tallinn / Estonia, OMX Helsinki / Finland, CAC 40 / France, DAX 30 / Germany, Athex Composite / Greece, Hang Seng / Hong Kong, Budapest Index (BUX) / Hungary, OMX Iceland All Share / Iceland, BSE 100 / India, Jakarta SE Composite / Indonesia, Ireland SE Overall / Ireland, Israel TA 100 / Israel, Milan MIDEX / Italy, Nikkei 225 / Japan, Amman SE Financial Market / Jordan, Korea SE Composite (KOSPI) / Korea, Kuwait KIC General / Kuwait, OMX Riga / Latvia, Lebanon Blom / Lebanon, OMX Vilnius / Lithuania, Luxemburg SE General / Luxemburg, KLCI Composite / Malaysia, MSE / Malta, Mexico IPC (BOLSA) / Mexico, AEX Index / Netherlands, NZX 50 / New Zealand, Oslo Exchange All Share / Norway, Oman Muscat Securities / Oman, Karachi SE 100 / Pakistan, Lima SE General (IGBL) / Peru, Phillipine SE (PSEI) / Philippines, Warsaw General Index / Poland, Portugal PSI General / Portugal, Doha Securities General Index / Qatar, BET Composite Index / Romania, Russia RTS Index / Russian Federation, All Share Index (TASI) / Saudi Arabia, Straits Times Index / Singapore, Slovak Share Index (SAX) / Slovakia, Slovene Stock Exchange Index (SBI 20) / Slovenia, Madrid SE General / Spain, Colombo SE All Share Index / Sri Lanka, OMX Stockholm / Sweden, Swiss Market Price Index / Switzerland, Taiwan SE Weighted / Taiwan, Bangkok SET Price Index / Thailand, ISE National 100 / Turkey, Kinto KINDEX / Ukraine, Abu Dhabi All Securities Index / United Arab Emirates, FTSE All Share / United Kingdom, NYSE Composite / United States, and Venezuela SE General / Venezuela. 


\section{B. Tables}

\begin{tabular}{|c|c|c|c|c|}
\hline & Random Effects & PP-ARCH(1) ${ }^{a}$ & PP-ARCH(2) & PP-GARCH(1,1) \\
\hline Regressor & \multicolumn{4}{|c|}{ Point estimate (z-score) $^{\text {b }}$} \\
\hline & \multicolumn{4}{|c|}{ Mean equation } \\
\hline$r_{w m p, t}$ & $\begin{array}{c}0.292^{* * *} \\
(6.27)\end{array}$ & $\begin{array}{c}0.335^{\text {*** }} \\
(5.95)\end{array}$ & $\begin{array}{c}0.246^{* * *} \\
(5.05)\end{array}$ & $\begin{array}{c}0.328^{* * *} \\
(7.82)\end{array}$ \\
\hline$r_{w m p, t-1}$ & $\begin{array}{c}0.555^{* * *} \\
(6.05)\end{array}$ & $\begin{array}{c}0.508^{* * *} \\
(4.75)\end{array}$ & $\begin{array}{c}0.430^{* * *} \\
(4.30)\end{array}$ & $\begin{array}{c}0.249^{* * *} \\
(3.11)\end{array}$ \\
\hline$r_{w m p, t-2}$ & $\begin{array}{c}-0.566^{* * *} \\
(-5.16)\end{array}$ & $\begin{array}{c}-0.445^{* * *} \\
(-3.57)\end{array}$ & $\begin{array}{c}-0.377^{* * * *} \\
(-3.29)\end{array}$ & $\begin{array}{c}-0.231^{* *} \\
(-2.37)\end{array}$ \\
\hline$r_{w m p, t-3}$ & $\begin{array}{c}0.672^{* * * *} \\
(6.33)\end{array}$ & $\begin{array}{c}0.547^{\text {**** }} \\
(4.87)\end{array}$ & $\begin{array}{c}0.398^{* * *} \\
(4.07)\end{array}$ & $\begin{array}{c}0.321^{* * *} \\
(3.37)\end{array}$ \\
\hline$r_{w m p, t-4}$ & $\begin{array}{c}-0.595^{* * *} \\
(-6.97)\end{array}$ & $\begin{array}{c}-0.443^{* * *} \\
(-5.03)\end{array}$ & $\begin{array}{c}-0.267^{* * *} \\
(-3.27)\end{array}$ & $\begin{array}{c}-0.292^{* * *} \\
(-3.96)\end{array}$ \\
\hline$r_{w m p, t-5}$ & $\begin{array}{c}0.287^{* * *} \\
(7.31) \\
\end{array}$ & $\begin{array}{c}0.202^{* * *} \\
(4.62)\end{array}$ & $\begin{array}{c}0.122^{* * *} \\
(2.92)\end{array}$ & $\begin{array}{c}0.157^{* * *} \\
(4.91)\end{array}$ \\
\hline$r_{s m b, t}$ & $\begin{array}{l}-0.003 \\
(-0.17)\end{array}$ & $\begin{array}{l}-0.027 \\
(-1.12)\end{array}$ & $\begin{array}{l}-0.036 \\
(-1.12)\end{array}$ & $\begin{array}{l}-0.004 \\
(-0.27)\end{array}$ \\
\hline$r_{s m b, t-1}$ & $\begin{array}{c}0.159^{* * *} \\
(8.32)\end{array}$ & $\begin{array}{c}0.178^{* *} \\
(6.61)\end{array}$ & $\begin{array}{c}0.194^{* * *} \\
(8.86)\end{array}$ & $\begin{array}{c}0.199^{* * *} \\
(9.72)\end{array}$ \\
\hline$r_{s m b, t-2}$ & $\begin{array}{c}0.128^{* * * *} \\
(6.69)\end{array}$ & $\begin{array}{c}0.141^{\text {**** }} \\
(6.12)\end{array}$ & $\begin{array}{c}0.078^{* *} \\
(2.58)\end{array}$ & $\begin{array}{c}0.126^{* * *} \\
(8.89)\end{array}$ \\
\hline$r_{s m b, t-3}$ & $\begin{array}{l}0.019 \\
(0.98) \\
\end{array}$ & $\begin{array}{l}0.028 \\
(1.22) \\
\end{array}$ & $\begin{array}{l}-0.001 \\
(-0.09)\end{array}$ & $\begin{array}{l}-0.008 \\
(-0.47) \\
\end{array}$ \\
\hline$r_{s m b, t-4}$ & $\begin{array}{c}-0.0001 \\
(-0.01) \\
\end{array}$ & $\begin{array}{l}0.024 \\
(1.22)\end{array}$ & $\begin{array}{l}0.074^{*} \\
(1.83)\end{array}$ & $\begin{array}{l}0.002 \\
(0.18)\end{array}$ \\
\hline$r_{s m b, t-5}$ & $\begin{array}{l}0.010 \\
(0.59)\end{array}$ & $\begin{array}{c}-0.0162 \\
(-0.58)\end{array}$ & $\begin{array}{l}0.011 \\
(0.60)\end{array}$ & $\begin{array}{l}0.022 \\
(1.49)\end{array}$ \\
\hline$r_{h m l, t}$ & $\begin{array}{c}0.054^{\text {**** }} \\
(6.59)\end{array}$ & $\begin{array}{c}0.0483 \\
(5.27) \\
\end{array}$ & $\begin{array}{c}0.025^{* *} \\
(2.14)\end{array}$ & $\begin{array}{c}0.028^{* * *} \\
(4.29)\end{array}$ \\
\hline$r_{h m l, t-1}$ & $\begin{array}{c}0.139^{\text {*** }} \\
(3.22)\end{array}$ & $\begin{array}{l}0.089^{*} \\
(1.74)\end{array}$ & $\begin{array}{l}0.115^{* *} \\
(2.50)\end{array}$ & $\begin{array}{l}0.023 \\
(0.64)\end{array}$ \\
\hline$r_{h m l, t-2}$ & $\begin{array}{c}-0.248^{* * *} \\
(-4.35)\end{array}$ & $\begin{array}{c}-0.209^{* * *} \\
(-3.36)\end{array}$ & $\begin{array}{c}-0.175^{\text {*** }} \\
(-2.75)\end{array}$ & $\begin{array}{l}-0.084^{*} \\
(-1.70)\end{array}$ \\
\hline$r_{h m l, t-3}$ & $\begin{array}{c}0.316^{* * * *} \\
(5.22)\end{array}$ & $\begin{array}{c}0.248^{* * *} \\
(3.56)\end{array}$ & $\begin{array}{c}0.171^{* * *} \\
(2.78)\end{array}$ & $\begin{array}{c}0.119^{* *} \\
(2.10)\end{array}$ \\
\hline$r_{h m l, t-4}$ & $\begin{array}{c}-0.321^{* * *} \\
(-5.97)\end{array}$ & $\begin{array}{c}-0.257^{* * *} \\
(-4.69)\end{array}$ & $\begin{array}{c}-0.171^{* * *} \\
(-3.40)\end{array}$ & $\begin{array}{c}-0.171^{* * * *} \\
(-3.80)\end{array}$ \\
\hline$r_{h m l, t-5}$ & $\begin{array}{c}0.290^{* * *} \\
(7.19)\end{array}$ & $\begin{array}{c}0.198^{* * *} \\
(4.31)\end{array}$ & $\begin{array}{c}0.118^{* * *} \\
(2.75)\end{array}$ & $\begin{array}{c}0.143^{* * *} \\
(4.41)\end{array}$ \\
\hline$r_{i, t-1}$ & $\begin{array}{l}-0.013 \\
(-1.47) \\
\end{array}$ & $\begin{array}{l}-0.062^{* *} \\
(-2.34)\end{array}$ & $\begin{array}{l}0.023^{*} \\
(1.88)\end{array}$ & $\begin{array}{c}0.011 \\
(1.44)\end{array}$ \\
\hline$r_{i, t-2}$ & $\begin{array}{l}-0.010 \\
(-0.67)\end{array}$ & $\begin{array}{l}-0.037^{* *} \\
(-2.05)\end{array}$ & $\begin{array}{l}0.033^{*} \\
(1.96) \\
\end{array}$ & $\begin{array}{c}0.023^{* * *} \\
(2.31)\end{array}$ \\
\hline$r_{i, t-3}$ & $\begin{array}{c}-0.013^{* *} \\
(-2.24)\end{array}$ & $\begin{array}{l}0.003 \\
(0.28)\end{array}$ & $\begin{array}{l}-0.015 \\
(-1.59)\end{array}$ & $\begin{array}{c}-0.019^{* *} \\
(-2.17)\end{array}$ \\
\hline$r_{i, t-4}$ & $\begin{array}{c}0.0043 \\
(0.57) \\
\end{array}$ & $\begin{array}{l}0.001 \\
(0.09) \\
\end{array}$ & $\begin{array}{l}-0.016 \\
(-1.43) \\
\end{array}$ & $\begin{array}{l}-0.005 \\
(-0.86) \\
\end{array}$ \\
\hline$r_{i, t-5}$ & $\begin{array}{c}-0.0077 \\
(-1.09)\end{array}$ & $\begin{array}{l}0.002 \\
(0.19)\end{array}$ & $\begin{array}{c}0.026^{* *} \\
(2.35)\end{array}$ & $\begin{array}{l}0.007 \\
(0.77)\end{array}$ \\
\hline intercept & $\begin{array}{c}-0.0429 \\
(-1.64)\end{array}$ & $\begin{array}{c}-0.045^{* *} \\
(-1.75)\end{array}$ & $\begin{array}{l}-0.007 \\
(-0.29)\end{array}$ & $\begin{array}{c}0.0004 \\
(0.02) \\
\end{array}$ \\
\hline
\end{tabular}




\begin{tabular}{|c|c|c|c|c|}
\hline Year effects $^{c}$ & included & included & included & included \\
\hline Month effects & included & included & included & included \\
\hline Day effects & included & included & included & Included \\
\hline \multicolumn{5}{|c|}{ Conditional Variance Equation } \\
\hline $\mathrm{ARCH}(1)$ & - & $\begin{array}{c}0.416^{* * *} \\
(12.84)\end{array}$ & $\begin{array}{c}0.298^{* * *} \\
(15.41)\end{array}$ & $\begin{array}{c}0.147^{* * *} \\
(16.20)\end{array}$ \\
\hline $\mathrm{ARCH}(2)$ & - & - & $\begin{array}{c}0.354^{* * *} \\
(8.69)\end{array}$ & - \\
\hline GARCH(1) & - & - & - & $\begin{array}{c}0.857^{* * *} \\
(90.05)\end{array}$ \\
\hline intercept & - & $\begin{array}{l}0.971^{* * *} \\
(25.66)\end{array}$ & $\begin{array}{l}0.652^{* * *} \\
(34.10)\end{array}$ & $\begin{array}{c}0.012^{* * *} \\
(4.25)\end{array}$ \\
\hline Log Likelihood & - & -78155.37 & -75874.70 & -72791.05 \\
\hline $\begin{array}{l}\text { LR Test }^{\text {d: }} \text { PP- } \\
\text { ARCH(2) vs. PP- } \\
\text { ARCH(1) }\end{array}$ & \multicolumn{4}{|c|}{$4561.34^{* * *}$} \\
\hline $\begin{array}{c}\text { LR Test: PP- } \\
\text { GARCH(1,1) vs. PP- } \\
\text { ARCH(2) }\end{array}$ & \multicolumn{4}{|c|}{$6167.30^{* * *}$} \\
\hline Observations & \multicolumn{4}{|c|}{49918} \\
\hline \multicolumn{5}{|c|}{$\begin{array}{l}\text { Notes: (a) PP-ARCH stands for Pooled Panel Autoregressive Conditional Heteroscedasticty, (b) } * * *, * *, * \text { denote } \\
\text { significance at the } 1,5 \text { and } 10 \text { percent level respectively, (c) Year, Month, Day effects denote } 3,11 \text {, and } 4 \text { zero / one } \\
\text { dummies identifying each year, month and day, (d) LR stands for Likelihood Ratio. }\end{array}$} \\
\hline
\end{tabular}




\begin{tabular}{|c|c|c|c|}
\hline \multicolumn{4}{|c|}{ Panel A: Overall Trade linkages } \\
\hline Regressor $^{d}$ & Linear & Quadratic & Cubic \\
\hline (trade) & $\begin{array}{l}-0.046^{*} \\
(-1.70)\end{array}$ & $\begin{array}{c}-0.178^{* * *} \\
(-2.99)\end{array}$ & $\begin{array}{c}-0.457^{\text {**** }} \\
(-4.58)\end{array}$ \\
\hline$(\text { trade })^{2}$ & - & $\begin{array}{l}0.006^{* *} \\
(2.06)\end{array}$ & $\begin{array}{c}0.042^{* * *} \\
(4.22)\end{array}$ \\
\hline$(\text { trade })^{3}$ & - & - & $\begin{array}{c}-0.009^{*} 10^{-11^{* * *}} \\
(-3.99)\end{array}$ \\
\hline$R^{2}$ & 0.028 & 0.079 & 0.144 \\
\hline Adjusted $R^{2}$ & 0.020 & 0.064 & 0.123 \\
\hline Observations & 125 & 125 & 125 \\
\hline \multicolumn{4}{|c|}{ Hypotheses tests } \\
\hline Cubic vs. linear ${ }^{\mathrm{e}}$ & - & - & $9.59^{* * *}$ \\
\hline Cubic vs. quadratic $^{f}$ & - & - & $15.88^{* * *}$ \\
\hline Quadratic vs. linear $^{\mathrm{g}}$ & - & $4.23^{* *}$ & - \\
\hline $\begin{array}{c}\text { Linkages not a diffusion } \\
\text { channel }^{\mathrm{h}}\end{array}$ & $2.90^{*}$ & $5.18^{* * *}$ & $8.35^{* * *}$ \\
\hline \multicolumn{4}{|c|}{ Panel B: Overall Financial linkages } \\
\hline Regressor $^{i}$ & Linear & Quadratic & Cubic \\
\hline$($ fina $)$ & $\begin{array}{l}-0.037^{* *} \\
(-2.08)\end{array}$ & $\begin{array}{l}-0.080^{*} \\
(-1.86)\end{array}$ & $\begin{array}{c}-0.364^{* * *} \\
(-2.87)\end{array}$ \\
\hline$(\text { fina })^{2}$ & - & $\begin{array}{l}0.001 \\
(1.49)\end{array}$ & $\begin{array}{l}0.032^{* *} \\
(2.40)\end{array}$ \\
\hline$(\text { fina })^{3}$ & - & - & $\begin{array}{c}-0.006^{*} 10^{-1}{ }^{* *} \\
(-2.28)\end{array}$ \\
\hline$R^{2}$ & 0.040 & 0.039 & 0.095 \\
\hline Adjusted $R^{2}$ & 0.019 & 0.021 & 0.069 \\
\hline Observations & 111 & 111 & 111 \\
\hline \multicolumn{4}{|c|}{ Hypotheses Tests } \\
\hline Cubic vs. linear & - & - & $3.70^{* *}$ \\
\hline Cubic vs. quadratic & - & - & $5.21^{* *}$ \\
\hline Quadratic vs. linear & - & 2.22 & - \\
\hline $\begin{array}{c}\text { Linkages not a diffusion } \\
\text { channel }\end{array}$ & $4.31^{* *}$ & 2.12 & $12.82^{* * *}$ \\
\hline \multicolumn{4}{|c|}{$\begin{array}{l}\text { Notes: (a) dependent variable is the abnormal return obtained from the PP-GARCH(1,1) model, (b) ***,**, * denote } \\
\text { significance at the } 1,5 \text { and } 10 \text { percent level respectively, (c) numbers in brackets denote t-tests based on robust } \\
\text { standard errors, (d) (trade) stands for overall trade linkages with the world, (e) F-test for the null hypotheses that the } \\
\text { coefficients of the cubic and square terms are jointly zero, (f) F-test for the null hypothesis that the coefficient of the } \\
\text { cubic term is zero, (g) F-test for the null hypothesis that the coefficient of the squared term is zero, (h) F-test for model } \\
\text { overall significance, (i) (fina) stands for overall financial linkages with the world. }\end{array}$} \\
\hline
\end{tabular}




\begin{tabular}{|c|c|c|c|}
\hline \multicolumn{4}{|c|}{ Panel A: Imports } \\
\hline Regressor $^{d}$ & Linear & Quadratic & Cubic \\
\hline$(i m p)$ & $\begin{array}{c}-0.098^{* *} \\
(-2.00)\end{array}$ & $\begin{array}{c}-0.257^{* *} \\
(-2.54)\end{array}$ & $\begin{array}{c}-0.928^{* * *} \\
(-4.65)\end{array}$ \\
\hline$(i m p)^{2}$ & - & $\begin{array}{l}0.013^{* *} \\
(2.20)\end{array}$ & $\begin{array}{c}0.170^{* * *} \\
(4.38)\end{array}$ \\
\hline$(i m p)^{3}$ & - & - & $\begin{array}{c}-0.006^{* * *} \\
(-4.28)\end{array}$ \\
\hline$R^{2}$ & 0.033 & 0.061 & 0.145 \\
\hline Adjusted $R^{2}$ & 0.025 & 0.046 & 0.124 \\
\hline Observations & 125 & 125 & 125 \\
\hline \multicolumn{4}{|c|}{ Hypotheses Tests } \\
\hline Cubic vs. linear ${ }^{\mathrm{e}}$ & - & - & $9.85^{* * *}$ \\
\hline Cubic vs. quadratic $^{f}$ & - & - & $18.32^{* * *}$ \\
\hline Quadratic vs. linear ${ }^{\mathrm{g}}$ & - & $4.83^{* *}$ & - \\
\hline $\begin{array}{c}\text { Linkages not a diffusion } \\
\text { channel }^{\mathrm{h}}\end{array}$ & $3.99^{* *}$ & $3.21^{* *}$ & $25.82^{* * *}$ \\
\hline \multicolumn{4}{|c|}{ Panel B: Exports } \\
\hline Regressor $^{\mathrm{i}}$ & Linear & Quadratic & Cubic \\
\hline$(\exp )$ & $\begin{array}{l}-0.077 \\
(-1.37)\end{array}$ & $\begin{array}{c}-0.507^{* *} \\
(-3.86)\end{array}$ & $\begin{array}{c}-0.608^{* * *} \\
(-2.54)\end{array}$ \\
\hline$(\exp )^{2}$ & - & $\begin{array}{c}0.046^{* * *} \\
(3.47)\end{array}$ & $\begin{array}{l}0.078 \\
(1.34)\end{array}$ \\
\hline$(\exp )^{3}$ & - & - & $\begin{array}{l}-0.002 \\
(-0.57)\end{array}$ \\
\hline$R^{2}$ & 0.020 & 0.111 & 0.113 \\
\hline Adjusted $R^{2}$ & 0.012 & 0.097 & 0.091 \\
\hline Observations & 125 & 125 & 125 \\
\hline \multicolumn{4}{|c|}{ Hypotheses Tests } \\
\hline Cubic vs. linear & - & - & $6.05^{* * *}$ \\
\hline Cubic vs. quadratic & - & - & 0.32 \\
\hline Quadratic vs. linear & - & $12.05^{* * *}$ & - \\
\hline $\begin{array}{c}\text { Linkages not a diffusion } \\
\text { channel }\end{array}$ & 1.87 & $7.65^{* * *}$ & $5.07^{* * *}$ \\
\hline \multicolumn{4}{|c|}{$\begin{array}{l}\text { Notes: (a) dependent variable is the abnormal return obtained from the PP-GARCH(1,1) model, (b) ***, **, * denote } \\
\text { significance at the } 1,5 \text { and } 10 \text { percent level respectively, (c) numbers in brackets denote t-tests based on robust } \\
\text { standard errors, (d) (imp) stands for import linkages with the world (e) F-test for the null hypotheses that the } \\
\text { coefficients of the cubic and square terms are jointly zero, (f) F-test for the null hypothesis that the coefficient of the } \\
\text { cubic term is zero, (g) F-test for the null hypothesis that the coefficient of the squared term is zero, (h) F-test for model } \\
\text { overall significance, (i) (exp) stands for export linkages with the world. }\end{array}$} \\
\hline
\end{tabular}




\begin{tabular}{|c|c|c|c|}
\hline \multicolumn{4}{|c|}{ Panel A: Equity } \\
\hline Regressor $^{d}$ & Linear & Quadratic & Cubic \\
\hline$(e q u)$ & $\begin{array}{l}-0.034^{* *} \\
(-2.25)\end{array}$ & $\begin{array}{l}-0.076^{* *} \\
(-2.01)\end{array}$ & $\begin{array}{l}-0.217^{* *} \\
(-2.18)\end{array}$ \\
\hline$(e q u)^{2}$ & 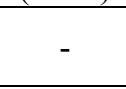 & $\begin{array}{l}0.001 \\
(1.63)\end{array}$ & $\begin{array}{l}0.015 \\
(1.63)\end{array}$ \\
\hline$(e q u)^{3}$ & - & - & $\begin{array}{c}-0.002 * 10^{-1} \\
(-1.51)\end{array}$ \\
\hline$R^{2}$ & 0.028 & 0.041 & 0.066 \\
\hline Adjusted $R^{2}$ & 0.019 & 0.023 & 0.040 \\
\hline Observations & 111 & 111 & 111 \\
\hline \multicolumn{4}{|c|}{ Hypotheses Tests } \\
\hline Cubic vs. linear ${ }^{\mathrm{e}}$ & - & - & 2.32 \\
\hline Cubic vs. quadratic $^{f}$ & - & - & 2.27 \\
\hline Quadratic vs. linear ${ }^{\mathrm{g}}$ & - & 2.66 & - \\
\hline $\begin{array}{c}\text { Linkages not a diffusion } \\
\text { channel }^{\mathrm{h}}\end{array}$ & $5.08^{* *}$ & $3.95^{* *}$ & $14.10^{* * *}$ \\
\hline \multicolumn{4}{|c|}{ Panel B: Debt } \\
\hline Regressor $^{\mathrm{i}}$ & Linear & Quadratic & Cubic \\
\hline$(d e b t)$ & $\begin{array}{l}-0.036^{*} \\
(-1.77)\end{array}$ & $\begin{array}{l}-0.099^{* *} \\
(-1.99)\end{array}$ & $\begin{array}{c}-0.410^{* * *} \\
(-3.39)\end{array}$ \\
\hline$(d e b t)^{2}$ & - & $\begin{array}{l}0.003 \\
(1.51)\end{array}$ & $\begin{array}{c}0.037^{* * *} \\
(3.06)\end{array}$ \\
\hline$(d e b t)^{3}$ & - & - & $\begin{array}{c}-0.008^{*} 10^{-1 * * *} \\
(-2.95)\end{array}$ \\
\hline$R^{2}$ & 0.026 & 0.041 & 0.106 \\
\hline Adjusted $R^{2}$ & 0.017 & 0.024 & 0.080 \\
\hline Observations & 111 & 111 & 111 \\
\hline \multicolumn{4}{|c|}{ Hypotheses Tests } \\
\hline Cubic vs. linear & - & - & $4.89^{* * *}$ \\
\hline Cubic vs. quadratic & - & - & $8.73^{* * *}$ \\
\hline Quadratic vs. linear & - & 2.29 & - \\
\hline $\begin{array}{l}\text { Linkages not a diffusion } \\
\text { channel }\end{array}$ & $3.14^{*}$ & 2.18 & $13.66^{* * *}$ \\
\hline \multicolumn{4}{|c|}{$\begin{array}{l}\text { Notes: (a) dependent variable is the abnormal return obtained from the PP-GARCH(1,1) model, (b) ***,**, * denote } \\
\text { significance at the } 1,5 \text { and } 10 \text { percent level respectively, (c) numbers in brackets denote t-tests based on robust } \\
\text { standard errors, (d) (equ) stands for equity linkages with the world, (e) F-test for the null hypotheses that the } \\
\text { coefficients of the cubic and square terms are jointly zero, (f) F-test for the null hypothesis that the coefficient of the } \\
\text { cubic term is zero, (g) F-test for the null hypothesis that the coefficient of the squared term is zero, (h) F-test for model } \\
\text { overall significance, (i) }(\text { debt) stands for debt linkages with the world. }\end{array}$} \\
\hline
\end{tabular}




\begin{tabular}{|c|c|c|c|}
\hline \multicolumn{4}{|c|}{ Panel A: Trade } \\
\hline Regressor $^{d}$ & Linear & Quadratic & Cubic \\
\hline$($ tradegzc $)$ & $\begin{array}{c}-0.323^{\text {*** }} \\
(-2.72)\end{array}$ & $\begin{array}{c}-1.165^{* * *} \\
(-2.92)\end{array}$ & $\begin{array}{c}-3.042^{* * *} \\
(-6.18)\end{array}$ \\
\hline$(\operatorname{tradeg} z c)^{2}$ & - & $\begin{array}{l}0.203^{*} \\
(1.89)\end{array}$ & $\begin{array}{c}1.331^{* * *} \\
(5.46)\end{array}$ \\
\hline$(\text { tradegzc })^{3}$ & - & - & $\begin{array}{l}-0.155^{* * *} \\
(-5.19)\end{array}$ \\
\hline$R^{2}$ & 0.081 & 0.147 & 0.261 \\
\hline Adjusted $R^{2}$ & 0.073 & 0.133 & 0.242 \\
\hline Observations & 121 & 121 & 121 \\
\hline \multicolumn{4}{|c|}{ Hypotheses Tests } \\
\hline Cubic vs. linear $^{\mathrm{e}}$ & - & - & $15.05^{* * *}$ \\
\hline Cubic vs. quadratic ${ }^{f}$ & - & - & $26.93^{* * *}$ \\
\hline Quadratic vs. linear ${ }^{\mathrm{g}}$ & - & $3.56^{*}$ & - \\
\hline $\begin{array}{c}\text { Linkages not a diffusion } \\
\text { channel }^{\mathrm{h}}\end{array}$ & $7.40^{* * *}$ & $8.14^{* * *}$ & $18.50^{* * *}$ \\
\hline \multicolumn{4}{|c|}{ Panel B: Financial } \\
\hline Regressor $^{\mathrm{i}}$ & Linear & Quadratic & Cubic \\
\hline$($ finagzc $)$ & $\begin{array}{l}-0.165 \\
(-1.56)\end{array}$ & $\begin{array}{l}-0.442 \\
(-1.51)\end{array}$ & $\begin{array}{c}-1.740^{* * *} \\
(-3.25)\end{array}$ \\
\hline$(\text { finagzc })^{2}$ & - & $\begin{array}{l}0.074 \\
(1.11) \\
\end{array}$ & $\begin{array}{c}0.920^{* * * *} \\
(2.81)\end{array}$ \\
\hline$(\text { finagzc })^{3}$ & - & - & $\begin{array}{c}-0.123^{* *} \\
(-2.57)\end{array}$ \\
\hline$R^{2}$ & 0.026 & 0.038 & 0.101 \\
\hline Adjusted $R^{2}$ & 0.015 & 0.016 & 0.070 \\
\hline Observations & 91 & 91 & 91 \\
\hline \multicolumn{4}{|c|}{ Hypotheses Tests } \\
\hline Cubic vs. linear & - & - & $4.20^{* *}$ \\
\hline Cubic vs. quadratic & - & - & $6.62^{* *}$ \\
\hline Quadratic vs. linear & - & 1.22 & - \\
\hline $\begin{array}{c}\text { Linkages not a diffusion } \\
\text { channel }\end{array}$ & 2.44 & 1.45 & $4.15^{* * *}$ \\
\hline \multicolumn{4}{|c|}{$\begin{array}{l}\text { Notes: (a) dependent variable is the abnormal return obtained from the PP-GARCH( }(1,1) \text { model, (b) ***,**,* denote } \\
\text { significance at the } 1,5 \text { and } 10 \text { percent level respectively, (c) numbers in brackets denote t-tests based on robust } \\
\text { standard errors, (d) (tradegzc) stands for bilateral trade linkages with the "ground-zero" country (e) F-test for the null } \\
\text { hypotheses that the coefficients of the cubic and square terms are jointly zero, (f) F-test for the null hypothesis that the } \\
\text { coefficient of the cubic term is zero, (g) F-test for the null hypothesis that the coefficient of the squared term is zero, (h) } \\
\text { F-test for model overall significance, (i) (finagzc) stands for bilateral financial linkages with the "ground-zero" } \\
\text { country. }\end{array}$} \\
\hline
\end{tabular}




\begin{tabular}{|c|c|c|c|}
\hline \multicolumn{4}{|c|}{$\begin{array}{l}\text { Table A6. Liquidity channel and abnormal returns III: Stock marke } \\
\text { trading }{ }_{a, b, c} \\
\text { Panel A: Stock market capitalization }\end{array}$} \\
\hline Regressor $^{d}$ & Linear & Quadratic & Cubic \\
\hline$(s m c)$ & $\begin{array}{l}-0.002^{* *} \\
(-2.43)\end{array}$ & $\begin{array}{l}-0.009^{* *} \\
(-2.39)\end{array}$ & $\begin{array}{c}-0.026^{* * *} \\
(-3.03)\end{array}$ \\
\hline$(s m c)^{2}$ & - & $\begin{array}{c}0.002 * 10^{-2} * \\
(1.98)\end{array}$ & $\begin{array}{c}0.001^{*} 10^{-1}{ }^{* * *} \\
(2.65)\end{array}$ \\
\hline$(s m c)^{3}$ & - & - & $\begin{array}{c}-0.002 * 10^{-4 * *} \\
(-2.48) \\
\end{array}$ \\
\hline$R^{2}$ & 0.025 & 0.047 & 0.077 \\
\hline Adjusted $R^{2}$ & 0.017 & 0.032 & 0.055 \\
\hline Observations & 125 & 125 & 125 \\
\hline \multicolumn{4}{|c|}{ Hypotheses Tests } \\
\hline Cubic vs. linear $^{\mathrm{e}}$ & - & - & $3.95^{* *}$ \\
\hline Cubic vs. quadratic ${ }^{f}$ & - & - & $6.15^{* *}$ \\
\hline Quadratic vs. linear ${ }^{\mathrm{g}}$ & - & $3.90^{*}$ & - \\
\hline $\begin{array}{c}\text { Linkages not a diffusion } \\
\text { channel }^{\mathrm{h}}\end{array}$ & $5.89^{* *}$ & $3.59^{* *}$ & $4.77^{* * *}$ \\
\hline \multicolumn{4}{|c|}{ Panel B: Value of stock trading } \\
\hline Regressor $^{i}$ & Linear & Quadratic & Cubic \\
\hline$(v s t)$ & $\begin{array}{c}-0.005^{* * *} \\
(-2.98)\end{array}$ & $\begin{array}{c}-0.010^{* * *} \\
(-3.01)\end{array}$ & $\begin{array}{l}-0.014^{*} \\
(-1.72)\end{array}$ \\
\hline$(v s t)^{2}$ & - & $\begin{array}{c}0.002^{*} 10^{-2 * *} \\
(2.31)\end{array}$ & $\begin{array}{c}0.0007 * 10^{-1} \\
(0.92)\end{array}$ \\
\hline$(v s t)^{3}$ & - & - & $\begin{array}{c}-0.0001 * 10^{-3} \\
(-0.66)\end{array}$ \\
\hline$R^{2}$ & 0.059 & 0.075 & 0.078 \\
\hline Adjusted $R^{2}$ & 0.052 & 0.060 & 0.055 \\
\hline Observations & 125 & 125 & 125 \\
\hline \multicolumn{4}{|c|}{ Hypotheses Tests } \\
\hline Cubic vs. linear & - & - & $2.91^{*}$ \\
\hline Cubic vs. quadratic & - & - & 0.44 \\
\hline Quadratic vs. linear & - & $5.34^{* *}$ & - \\
\hline $\begin{array}{c}\text { Linkages not a diffusion } \\
\text { channel }\end{array}$ & $8.88^{* * * *}$ & $5.93^{* * *}$ & $4.90^{* * *}$ \\
\hline \multicolumn{4}{|c|}{$\begin{array}{l}\text { Notes: (a) dependent variable is the abnormal return obtained from the PP-GARCH(1,1) model, (b) ***,**,* denote } \\
\text { significance at the } 1,5 \text { and } 10 \text { percent level respectively, (c) numbers in brackets denote t-tests based on robust } \\
\text { standard errors, (d) }(s m c) \text { stands for the ratio of stock market capitalization to GDP, e) F-test for the null hypotheses } \\
\text { that the coefficients of the cubic and square terms are jointly zero, (f) F-test for the null hypothesis that the coefficient } \\
\text { of the cubic term is zero, (g) F-test for the null hypothesis that the coefficient of the squatted term is zero, (h) F-test for } \\
\text { model overall significance, (i) (vst) stands for the ratio of value of stock trading to GDP. }\end{array}$} \\
\hline
\end{tabular}




\section{Tables}

\begin{tabular}{|c|c|c|c|c|c|}
\hline \multicolumn{6}{|c|}{ World integration channel } \\
\hline $\operatorname{Proxy}^{\mathrm{a}, \mathrm{b}, \mathrm{c}, \mathrm{d}, \mathrm{e}}$ & Mean ${ }^{f}$ & Std. Dev. & Min & Max & Obs \\
\hline (trade) & 2.98 & 4.77 & 0.08 & 29.47 & 133 \\
\hline$(\mathrm{imp})$ & 1.47 & 2.65 & 0.04 & 18.06 & 133 \\
\hline$(\exp )$ & 1.48 & 2.25 & 0.02 & 11.41 & 133 \\
\hline$($ fina $)$ & 3.16 & 6.46 & 0.003 & 38.27 & 109 \\
\hline$(e q u)$ & 3.34 & 7.48 & 0.001 & 47.50 & 109 \\
\hline$(d e b t)$ & 3.04 & 5.99 & 0.001 & 31.88 & 109 \\
\hline \multicolumn{6}{|c|}{ Bilateral integration channel } \\
\hline$($ tradegzc $)$ & 0.68 & 1.08 & 0.01 & 5.69 & 127 \\
\hline$($ finagzc $)$ & 0.81 & 1.41 & 0.00 & 9.54 & 100 \\
\hline \multicolumn{6}{|c|}{ Liquidity channel } \\
\hline$(s m c)$ & 77.93 & 71.17 & 3.00 & 401.00 & 133 \\
\hline$(v s t)$ & 49.64 & 61.75 & 0.00 & 350.00 & 132 \\
\hline
\end{tabular}

Notes: (a) (trade),(imp), (exp) stand for overall trade, import, and export linkages with the world respectively, (b) (fina), (equ), (debt) stand for overall financial, equity and debt linkages with the world respectively, (c) (tradegzc), (finagzc) stand for bilateral trade and financial linkages with the "ground-zero" country respectively, (d) (smc), (vst) stand for the ratio of stock market capitalization and value of stock trading to GDP respectively, (e) Original data sources: (trade), (imp), (exp); IMF's International Financial Statistics, (fina), (equ), (debt); IMF's Coordinated Portfolio Investment Survey, (tradegzc), (finagzc); UN's Commodity Trade Statistics Database, (smc), (vst); World Bank's World Development

Indicators, and own calculations, (f) Mean, Std. Dev, Min, Max, Obs, stand for the sample mean, standard deviation, maximum, minimum, and number of observations respectively. 


\begin{tabular}{|c|c|c|c|c|c|c|c|c|c|c|}
\hline & (trade) & $(i m p)$ & $(\exp )$ & $($ fina $)$ & $(e q u)$ & $(d e b t)$ & (tradegzc) & (finagzc) & $(s m c)$ & $(v s t)$ \\
\hline (trade) & 1.00 & - & - & - & - & - & - & - & - & - \\
\hline$(i m p)$ & 0.96 & 1.00 & - & - & - & - & - & - & - & - \\
\hline$(\exp )$ & 0.96 & 0.87 & 1.00 & - & - & - & - & - & - & - \\
\hline$($ fina $)$ & 0.85 & 0.92 & 0.78 & 1.00 & - & - & - & - & - & - \\
\hline$(e q u)$ & 0.76 & 0.89 & 0.68 & 0.97 & 1.00 & - & - & - & - & - \\
\hline$(d e b t)$ & 0.87 & 0.92 & 0.82 & 0.98 & 0.92 & 1.00 & - & - & - & - \\
\hline (tradegzc) & 0.44 & 0.28 & 0.35 & 0.27 & 0.17 & 0.33 & 1.00 & - & - & - \\
\hline$($ finagzc $)$ & 0.46 & 0.40 & 0.37 & 0.47 & 0.42 & 0.48 & 0.58 & 1.00 & - & - \\
\hline$(s m c)$ & 0.11 & 0.21 & 0.07 & 0.21 & 0.27 & 0.15 & -0.05 & 0.15 & 1.00 & - \\
\hline$(v s t)$ & 0.35 & 0.52 & 0.37 & 0.48 & 0.51 & 0.44 & 0.18 & 0.26 & 0.65 & 1.00 \\
\hline
\end{tabular}

Notes: (a) (trade), (imp), (exp) stand for overall trade, import, and export linkages with the world respectively, (b) (fina), (equ), (debt) stand for overall financial, equity and debt linkages with the world respectively, (c) (tradegzc), (finagzc) stand for bilateral trade and financial linkages with the "ground-zero" country respectively, (d) $(s m c),(v s t)$ stand for the ratio of stock market capitalization and value of stock trading to GDP respectively. 


\begin{tabular}{|c|c|c|c|c|c|}
\hline City & Date & Timing & Location & Deaths & Injuries \\
\hline Madrid & $\begin{array}{c}\text { March } 11^{\text {th }} \\
2004\end{array}$ & $\begin{array}{l}\text { 7:37 am local time } \\
(6: 37 \text { am GMT })\end{array}$ & Train stations & 191 & 1876 \\
\hline London & July $7^{\text {th }} 2005$ & $\begin{array}{c}8: 50-9: 47 \text { am local } \\
\text { time }\end{array}$ & Underground trains, bus & 54 & 700 \\
\hline
\end{tabular}




\begin{tabular}{|c|c|c|c|}
\hline $\begin{array}{c}\text { Parameter / } \\
\text { Diffusion channel proxy }^{\mathrm{e}}\end{array}$ & (trade) & $(i m p)$ & $(\exp )$ \\
\hline$\gamma_{m, 1}$ & $\begin{array}{c}-0.457^{* * *} \\
(-4.58)\end{array}$ & $\begin{array}{c}-0.928^{* * *} \\
(-4.65)\end{array}$ & $\begin{array}{l}-0.507^{* *} \\
(-3.86)\end{array}$ \\
\hline$\gamma_{m, 2}$ & $\begin{array}{c}0.042^{* * *} \\
(4.22)\end{array}$ & $\begin{array}{c}0.170^{* * * *} \\
(4.38)\end{array}$ & $\begin{array}{c}0.046^{* 3 *} \\
(3.47)\end{array}$ \\
\hline$\gamma_{m, 3}$ & $\begin{array}{c}-0.009^{*} 10^{-1 * * *} \\
(-3.99)\end{array}$ & $\begin{array}{c}-0.006^{* * *} \\
(-4.28)\end{array}$ & - \\
\hline$R^{2}$ & 0.144 & 0.145 & 0.111 \\
\hline Adjusted $R^{2}$ & 0.123 & 0.124 & 0.097 \\
\hline Observations & 125 & 125 & 125 \\
\hline Diffusion channel not in operation ${ }^{\mathrm{h}}$ & $8.35^{* * * *}$ & $25.82^{* * *}$ & $7.65^{* * *}$ \\
\hline \multicolumn{4}{|c|}{$\begin{array}{l}\text { Notes: (a) dependent variable is the abnormal return obtained from the PP-GARCH(1,1) model, (b) ***,**,* denote } \\
\text { significance at the } 1,5 \text { and } 10 \text { percent level respectively, (c) numbers in brackets denote t-tests based on robust } \\
\text { standard errors, (d) each column reports the estimation results from the preferred specification (full results for the } \\
\text { linear, quadratic and cubic models are provided in the Appendix, (e) (trade), (imp), (exp) stand for overall trade, } \\
\text { import, and export linkages with the world respectively, (f) F-test for the null hypotheses that the coefficients of the } \\
\text { cubic and square terms are jointly zero, (g) F-test for the null hypothesis that the coefficient of the cubic term is zero, } \\
\text { (h) F-test for model overall significance. }\end{array}$} \\
\hline
\end{tabular}




\begin{tabular}{|c|c|c|c|}
\hline $\begin{array}{c}\text { Parameter / } \\
\text { Diffusion channel proxy }\end{array}$ & (fina) & $(e q u)$ & $(d e b t)$ \\
\hline$\gamma_{m, 1}$ & $\begin{array}{c}-0.364^{* * *} \\
(-2.87)\end{array}$ & $\begin{array}{l}-0.034^{* *} \\
(-2.25)\end{array}$ & $\begin{array}{l}-0.410^{* * *} \\
(-3.39) \\
\end{array}$ \\
\hline$\gamma_{m, 2}$ & $\begin{array}{l}0.032^{* * *} \\
(2.40)\end{array}$ & - & $\begin{array}{c}0.037^{* * *} \\
(3.06)\end{array}$ \\
\hline$\gamma_{m, 3}$ & $\begin{array}{c}-0.006^{*} 10^{-1 * *} \\
(-2.28) \\
\end{array}$ & - & $\begin{array}{c}-0.008 * 10^{-1 * * *} \\
(-2.95)\end{array}$ \\
\hline$R^{2}$ & 0.095 & 0.028 & 0.106 \\
\hline Adjusted $R^{2}$ & 0.069 & 0.019 & 0.080 \\
\hline Observations & 111 & 111 & 111 \\
\hline Diffusion channel not in operation $^{\mathrm{h}}$ & $12.82^{* * * *}$ & $5.08^{* * *}$ & $13.66^{* * *}$ \\
\hline
\end{tabular}

Notes: (a) dependent variable is the abnormal return obtained from the PP-GARCH(1,1) model, (b) ***, **, * denote significance at the 1,5 and 10 percent level respectively, (c) numbers in brackets denote t-tests based on robust standard errors, (d) each column reports the estimation results from the preferred specification (full results for the linear, quadratic and cubic models are provided in the Appendix, (e) (fina), (equ), (debt) stand for overall financial, equity and debt linkages with the world respectively, (f) F-test for the null hypotheses that the coefficients of the cubic and square terms are jointly zero, (g) F-test for the null hypothesis that the coefficient of the cubic term is zero, (h) Ftest for model overall significance. 


\begin{tabular}{|c|c|c|c|c|}
\hline \multirow{2}{*}{$\begin{array}{c}\text { Diffusion channel } \\
\text { Parameter / } \\
\text { Diffusion channel proxy }\end{array}$} & \multicolumn{2}{|c|}{ Linkages with "ground-zero" country } & \multicolumn{2}{|c|}{ Liquidity $^{f}$} \\
\hline & $($ tradegzc $)$ & $($ finagzc $)$ & $(s m c)$ & $(v s t)$ \\
\hline$\gamma_{m, 1}$ & $\begin{array}{c}-3.042^{* * *} \\
(-6.18)\end{array}$ & $\begin{array}{l}-1.740^{* * *} \\
(-3.25)\end{array}$ & $\begin{array}{l}-0.026^{* * *} \\
(-3.03)\end{array}$ & $\begin{array}{c}-0.010^{* * *} \\
(-3.01)\end{array}$ \\
\hline$\gamma_{m, 2}$ & $\begin{array}{c}1.331^{* * *} \\
(5.46)\end{array}$ & $\begin{array}{c}0.920^{* * *} \\
(2.81)\end{array}$ & $\begin{array}{c}0.001^{*} 10^{-1}{ }^{* * *} \\
(2.65)\end{array}$ & $\begin{array}{c}0.002^{*} 10^{-2 * *} \\
(2.31)\end{array}$ \\
\hline$\gamma_{m, 3}$ & $\begin{array}{c}-0.155^{* * *} \\
(-5.19)\end{array}$ & $\begin{array}{l}-0.123^{* *} \\
(-2.57)\end{array}$ & $\begin{array}{c}-0.002^{*} 10^{-4 * *} \\
(-2.48)\end{array}$ & - \\
\hline$R^{2}$ & 0.261 & 0.101 & 0.077 & 0.075 \\
\hline Adjusted $R^{2}$ & 0.242 & 0.070 & 0.055 & 0.060 \\
\hline Observations & 121 & 91 & 125 & 125 \\
\hline $\begin{array}{l}\text { Diffusion channel not in } \\
\text { operation }^{\mathrm{i}}\end{array}$ & $18.50^{* * *}$ & $4.15^{* * *}$ & $4.77^{* * *}$ & $5.93^{* * *}$ \\
\hline \multicolumn{5}{|c|}{$\begin{array}{l}\text { Notes: (a) dependent variable is the abnormal return obtained from the PP-GARCH }(1,1) \text { model, (b) } * * *, * *, * \text { denote } \\
\text { significance at the } 1,5 \text { and } 10 \text { percent level respectively, (c) numbers in brackets denote t-tests based on robust } \\
\text { standard errors, (d) each column reports the estimation results from the preferred specification (full results for the } \\
\text { linear, quadratic and cubic models are provided in the Appendix, (e) (tradegzc), (finagzc) stand for bilateral trade } \\
\text { and financial linkages with the "ground-zero" country respectively, (f) }(s m c),(v s t) \text { stand for the ratio of stock } \\
\text { market capitalization and value of stock trading to GDP respectively, (g) F-test for the null hypotheses that the } \\
\text { coefficients of the cubic and square terms are jointly zero, (h) F-test for the null hypothesis that the coefficient of the } \\
\text { cubic term is zero, (i) F-test for model overall significance. }\end{array}$} \\
\hline
\end{tabular}




\begin{tabular}{|c|c|}
\hline Regressor $^{\mathrm{d}}$ & Point estimate (t-test) \\
\hline (trade) & $\begin{array}{l}-0.120 \\
(-0.85)\end{array}$ \\
\hline$(\text { trade })^{2}$ & $\begin{array}{l}0.017 \\
(1.29)\end{array}$ \\
\hline$(\text { trade })^{3}$ & $\begin{array}{c}-0.004 * 10^{-1} \\
(-1.43)\end{array}$ \\
\hline$($ tradegzc $)$ & $\begin{array}{c}-2.671^{\text {**** }} \\
(-4.33) \\
\end{array}$ \\
\hline$(\text { tradegzc })^{2}$ & $\begin{array}{l}1.161^{* * *} \\
(4.21)\end{array}$ \\
\hline$(\text { tradegzc })^{3}$ & $\begin{array}{c}-0.138^{* * *} \\
(-4.28) \\
\end{array}$ \\
\hline$(s m c)$ & $\begin{array}{l}-0.013 \\
(-1.49) \\
\end{array}$ \\
\hline$(s m c)^{2}$ & $\begin{array}{l}0.008 * 10^{-2} \\
(1.60)\end{array}$ \\
\hline$(s m c)^{3}$ & $\begin{array}{c}-0.001 * 10^{-4} * \\
(-1.72)\end{array}$ \\
\hline$R^{2}$ & 0.297 \\
\hline Adjusted $R^{2}$ & 0.240 \\
\hline Observations & 121 \\
\hline \multicolumn{2}{|c|}{ Hypotheses Tests } \\
\hline $\begin{array}{c}\text { World integration channel not a diffusion } \\
\text { mechanism }\end{array}$ & 1.12 \\
\hline $\begin{array}{c}\text { Bilateral integration channel not a diffusion } \\
\text { mechanism }^{\mathrm{f}}\end{array}$ & $9.69^{* * *}$ \\
\hline Liquidity channel not a diffusion mechanism $^{\mathrm{g}}$ & 1.70 \\
\hline Overall significance $^{\mathrm{h}}$ & $7.72^{* * *}$ \\
\hline \multicolumn{2}{|c|}{$\begin{array}{l}\text { Notes: (a) dependent variable is the abnormal return obtained from the PP-GARCH(1,1) model, (b) }{ }^{* * *}, * *, * \text { denote } \\
\text { significance at the } 1,5 \text { and } 10 \text { percent level respectively, (c) numbers in brackets denote t-tests based on robust } \\
\text { standard errors, (d) }(\text { trade }),(\text { tradegzc }) \text {, and }(s m c) \text { stand for overall trade linkages with the world, bilateral trade } \\
\text { linkages with the "ground-zero" country, and stock market capitalization over GDP respectively, (e) F-test for the null } \\
\text { hypothesis that the coefficients of }(\text { trade }),(\text { trade })^{2},(\text { trade })^{3} \text { are jointly zero, (f) F-test for the null hypotheses that the } \\
\text { coefficients of }(\text { tradegzc }),(\text { tradegzc })^{2},(\text { tradegzc })^{3} \text { are jointly zero, (g) F-test for the null hypothesis that the } \\
\text { coefficients of }(s m c),(s m c)^{2},(s m c)^{3} \text { are jointly zero, (h) F-test for model overall significance. }\end{array}$} \\
\hline
\end{tabular}

